\title{
Foucault and School Discipline: Reflections on South Africa
}

\author{
Victor Pitsoe \\ College of Education University of South Africay \\ Email: pitsovj@unisa.ac.za \\ Moketsi Letseka \\ College of Education University of South Africay \\ Email: letsem@unisa.ac.za
}

\section{Doi:10.5901/mjss.2014.v5n23p1525}

\begin{abstract}
Discipline in schools, as a thorny issue facing the current South African education system, has been and continues to be a global concern. With the advent of the new democratic dispensation in 1994, adoption of South Africa's 1996 Constitution, ratification of human rights and children's rights, and banning of corporal punishment, disciplinary problems escalated in schools. Central to this paper is the assumption that repressive and authoritarian forms of discipline perpetuate domination. The purpose of this article is to offer a philosophical account and theoretical framework for the management of discipline in schools that is compatible with the Restorative Justice Principles and democratic values. The paper draws on the ideas of French philosopher Michel Foucault as conceptual tools to try and understand the politics of the escalating school disciplinary problems and to provide an alternative framework for re-imagining the practice of school discipline.
\end{abstract}

Keywords: Michel Foucault; discipline, corporal punishment, docile bodies, Restorative Justice;

\section{Introduction}

Globally, school disciplinary problems and challenges have long been some of the most dismaying and unsettling aspects of education. Despite the fact that discipline is such a fluid social and porous construct, it is critical to effective and efficient management of schools. As Freire (1998:86) observes, discipline is a necessary condition for effective action in the social world. For Onderi and Odera (2012:711), discipline is the pillar for the success of a school in academic and extracurricular activities. Without discipline a school or organization cannot function optimally in order to achieve its goals and vision. Onderi and Odera (2012) contend that discipline in a school creates an orderly atmosphere in which meaningful achievement of learning can take place and positive values, social skills and attitudes can be inculcated. Historically, the most common means of maintaining discipline in schools was through corporal punishment. In South Africa during apartheid corporal punishment was legalised and used mainly as a corrective strategy to maintain discipline in public schools.

For us, school discipline as an educational management area and a policy imperative, is central to effective teaching and learning. In particular, discipline is critical in the attainment of Education for All (EFA) policy ideals. In the 1980s, Wayson and Lasley (1984:419) conceived discipline as "the display of behaviour that is socially agreed upon as appropriate in a particular situation". For Skiba, Eckes and Brown (2009:1074), "school discipline has been defined as having two main purposes: (a) ensuring the safety of those within the school; and (b) creating an environment conducive to learning". Thus the ability of teachers to maintain discipline is regarded as crucial to engendering socially agreed upon behaviour amongst the youngsters they are entrusted to educate. Following the advent of the new democratic dispensation in 1994, adoption of the 1996 Constitution, ratification of human rights and children's rights, corporal punishment was officially banned in South Africa. And yet the banishment seems to have resulted in the escalation of school disciplinary problems. Notwithstanding good strides of excellence in post-apartheid education transformation, a significant number research (Ndofirepi et al., 2012; du Preez \& Roux, 2010; Hawkins, 2009; Deacon, 2006; Christie, 1998) claims that poor discipline in public schools has become a major concern following the abolishment of corporal punishment by the National Department of Education. Whether it is viewed as moulding or domination, the traditional school discipline is slowly losing ground. The purpose of this paper is to offer a theoretical framework for the re-imagining discipline in schools that is consistent with liberal democratic values and the Restorative Justice Principles. Restorative 
justice is perhaps best understood as providing teachers with a foundation or platform from which they can launch their own programs of school discipline.

Central to this paper is the assumption that repressive and authoritarian discipline exacerbates behavioural problems in schools and perpetuates domination. Our view is that in unpacking the traditional school discipline practices and approaches, we should move away from the flawed world views that are inclined to positivism. Within this context, the questions we ask are, (1) To what extent do democratic changes weaken the structural and ideological foundations of traditional school discipline practice in a pluralistic society? (2) What role can Restorative Justice play in the school discipline theory and practice? To answer these questions, we draw upon Restorative Justice Theory and the work of French philosopher Michel Foucault as conceptual tools for understanding the politics of the escalating school disciplinary problems. This paper is divided into four sections. First, we conceptualise the notion of discipline, and argue that when discipline is conflated with repression it culminates in the creation of 'docile bodies'. Second, we explore traditional school discipline practices. We argue that they perpetuate a Calvinist hegemony that is incompatible with the notion of selfdiscipline. Third, we debate the restorative justice framework, which is characterised by, among others, 'dialogue and negotiation', focus on problem-solving, restitution, and accountability. In the final section we provide some concluding remarks.

\section{Conceptualzing Discipline}

This section provides a conceptualization of the notion of discipline: as power, that is, as coercive control. The section also explores discipline as a potential recipe for turning individuals into 'docile bodies'.

\subsection{Discipline as power}

From the outset we recognise that the notion of 'discipline' is widely conceived - it has differing, and even blurred meanings, as well as disparate interpretations. These varying conceptions are offered by various scholars (Ndofirepi et al., 2012; Nakpodia 2010; Yang 2009; Dartnell, 2008; Mertus \& Rawls, 2008; Leatherman, 2008; Mokhele, 2006; Foucault, 1995). Regardless of these considerable variations and contestations around the concept of 'discipline', we should hasten to emphasise that there is a common thread running through them. And that is the view on discipline as:

- Coercive control, which is based on the use of threats;

- Utilitarian control, which is based on the use of incentives and material rewards;

- Symbolic control, which focuses on prestige, esteem or social symbols such as love and acceptance; and

- Contextual, which rejects a "one-size-fits-all" problem solving of learner behaviour.

However, some scholars (Yang, 2009; Dartnell, 2008; Mertus \& Rawls, 2008; Leatherman, 2008; Foucault, 1995) regard discipline and punishment as two sides of the same coin - punishment as imposing discipline and/or compelling obedience. Among the exponents of discipline and punishment Michel Foucault stands out for his dedication and commitment to challenging states sovereignty and dominant ideology, with discipline and punishment at the epicentre of his scholarship. It is against this backdrop that in this paper we draw on Foucault's works, especially his book, Discipline and Punish. For Foucault, discipline is a type of power, a modality for its exercise, comprising a whole set of instruments, techniques, and procedures. It is Foucault's (1995:25) contention that power relations have an immediate hold upon the docile body. He writes: "they invest it, mark it, train it, torture it, force it to carry out tasks, to perform ceremonies, to emit signs. This political investment of the body is bound up, in accordance with complex reciprocal relations, with its economic use; it is largely as a force of production that the body is invested with relations of power and domination". The learners in schools can be easily turned into 'docile bodies' by the very school which purports to provide them with 'education'. For instance, as Foucault (1995: 121) notes, "a strict time-table, a system of prohibitions and obligations, continual supervision, exhortations, religious readings, a whole complex of methods 'to draw towards good' and 'to tum away from evil' held the prisoners in its grip from day to day.

While discipline and punishment tend to be viewed in negative terms, i.e., as the power to repress, violate, destroy, censor or silence, Foucault's (1995) view is that the two are a key aspect of power and how power is exercised. Foucault's views on discipline and punishment as modalities of power offer us useful ways for re-imagining the use and/or misuse of power in classroom management. For instance, he argues that disciplinary power is an efficient means of governing over mass numbers of people and of achieving the maximum amount of control with the minimum amount of resources (Foucault, 1995:220). Thus "in the space of domination disciplinary power manifests its potency, essentially, by arranging objects. The examination, as it were, is the ceremony of this objectification" (Foucault, 1995:187). Foucault 
(1995: 219) notes that disciplinary power works by fixing movement. He writes: "that is why discipline fixes; it arrests or regulates movements; it clears up confusion; it dissipates compact groupings of individuals wandering about the country in unpredictable ways; it establishes calculated distributions".

\subsection{Discipline and 'docile bodies'}

Foucault was particularly interested in the relationship between discipline and the 'docile bodies'. He argues that the body becomes docile in so far as it can be subjected, used, transformed and/or improved (Foucault, 1995:136). It is his contention that "discipline produces subjected and practised bodies, that is, 'docile' bodies. Discipline increases the force of the body (in economic terms of utility) and diminishes these same forces (in political terms of obedience)" (Foucault, 1995:138). In short, discipline turns bodies into "a relation of strict subjection". It is worthwhile noting that discipline is exercised in all institutions of social life, whether it is in schools, at work, in prisons, in churches, or hospitals, everyone involved is subject to some form of discipline. Foucault (1995) asserts any social institution is founded upon the interrelationships between the concepts of power, knowledge and the body. The body's visibility lends it to being easily controlled by political, economic and educational processes. Foucault shows that discipline is an art of the human body and a method of its mastery. For him, in its most general sense, discipline is a "political anatomy of detail" which operates upon individual movements and gestures until it eventually builds them into a recognizable shape.

A classic illustration of the notion of 'docile bodies' can be found in the lyrics of Nigerian legendary Afrobeat musician Fela Anikulapu Kuti's provocative song 'Zombie'. In 'Zombie' Fela portrays soldiers as more like 'puppets on the string' who respond to orders from their superiors in robotic fashion, without thinking or questioning the implications of their reactions. For instance, a senior military officer barks instructions to soldiers to "go and kill", or "go and die", and the soldiers will simply carry out the instructed as they are ordered, because that is what soldiers do: "follow orders from their superiors". For Fela, the military drills that soldiers perform as a central part of their training epitomise what it means to be a 'Zombie':

"Quick march!

Slow march!

Left turn!

Right turn!

About turn!

Double up!

Salute!

Open your hat!

Stand at ease!

Salute!

Fall in!

Fall out!

Fall down!

Get ready!

Halt!

Order!

Dismiss.

In the ancient regime parents were also susceptible to being turned into 'docile bodies' by the schools where their children studied. As Foucault (1995:211) notes, "the Christian School must not simply train docile children; it must also make it possible to supervise the parents, to gain information as to their way of life, their resources, their piety, their morals. The school tends to constitute minute social observatories that penetrate even to the adults and exercise regular supervision over them: the bad behaviour of the child, or his absence, is a legitimate pretext for one to go and question the neighbours, especially if there is any reason to believe that the ffamily will not tell the truth". The last sentence is no doubt instructive. What we are able to gleam from Foucault's observation is that in educating the child the Christian school occupies a moral high position. As Foucault illustrates, "one can then go and question the parents themselves, to find out whether they know their catechism and the prayers, whether they are determined to root out the vices of their children". Thus the Christian school colonises the family by not only turning the children into 'docile bodies', but by also reducing their parents 'docility' as well in so far as the perceived 'proper' education of the children is concerned. Foucault argues that in ancient European regimes 'punishment' was synonymous with 'torture'. For instance, forced labour or imprisonment were a means of ensuring that the condemned is deprived of liberty. He notes that "forced labour is a form 
of incarceration. The convict-ship is an open-air prison. Detention, reclusion, imprisonment for a minor offence are in a sense merely different names for one and the same punishment" (Foucault, 1995:115).

We want to note that how ideas and thoughts are organised in written and spoken language in the social construction of school discipline (as historical, cultural and political ritual) can be very problematic. While theories of social reproduction may, conceivably, give a basis for understanding how and why inequalities are reproduced, in this section, we want to argue that discipline is both an expression of and a tool for the exercise of power. It manifests in historical, racial and socioeconomic inequalities. We premise our argument on the assumption that an ideology always exists and is inherent in the form of an apparatus (discipline). Discipline, as an Ideological State Apparatus, can be used in a subtle way to ensure that there exists a reproduction of, and submission to the ruling ideology. Discipline perpetuates systems of inequality that promote a capitalist agenda. Most importantly, discipline encourages the production of docile bodies and transmits the technical knowledge required to develop political hegemony. Thus, in Foucault's terms the graduates are the new 'docile bodies' of a new social order who have 'agency' only to the extent that they adopt the prescribed agenda, follow the rituals and co-operate in putting the new policy prescriptions into practice (Dwyer, 2006). Foucault used the term docility to explain how control and power are achieved through the administration of discipline.

A body is docile, Foucault explains, when it is both obedient and teachable. In the Panoptic, the human body, watched constantly, begins to achieve the desired malleability, the subservient demeanour, and the repentant posture. One could even contend that successful traditional school discipline creates 'docile bodies'. Discipline, docility and surveillance are perhaps the most glaring practices in schools. Foucault's account of power relations is useful for our purpose in this paper in that it underscores the fact that docility and surveillance are critical in understanding disciplinary techniques in a school context. Disciplinary techniques, which produce and constitute knowledge, include constant surveillance, the ritualised use of the examination, the use of timetables to regulate conduct for each moment of the day, and a plethora of documentation such as files, records, charts, statistics, assessment, and the processes of classification and profiling. All are aimed at sustaining the hierarchical nature of most formal institutions such as schools.

To briefly summarise, in this section we highlighted the fact that the exercise of discipline has the potential to create 'docile bodies'. We drew on the work of Michel Foucault (1995), whose contention is that the body is docile when it is both obedient and teachable. When subjected to constant surveillance the human body is able to achieve the desired malleability, to adopt the subservient demeanour, as well as the repentant posture. As Mertus and Rawls (2008:34) attest, the process of torture only serves to expedite docility such that "the body interrogated in torture [constitutes] the point of application of the punishment and the locus of extortion of truth". As educators our concern is ways in which the above analysis of discipline plays itself out in the schools and in classrooms. In the next section we explore traditional practices of discipline in schools.

\section{Traditional School Discipline Practices}

In this section we venture into the casual relationship between the traditional school discipline and the, that traditional school discipline and corporal punishment have a symbiotic relationship. At a conceptual level traditional school discipline in the South African schools was informed by cultural practices, Victorian, behaviourist, and Calvinist world views. What these world views did was to perpetuated Calvinist hegemony, docile bodies and social reproduction. They conflated corporal punishment with 'good discipline'. Moreover, they subscribed to the view that certain Christian values are a recipe for discipline in schools. This position ignores the potential role of others in religions in a pluralistic and circular society.

From Victorian and Calvinist world views, the conception of discipline is premised on the supposition of "spare the rod, spoil the child". It holds the view that spanking is an effective means of discipline for students. This supposition takes its shape from Proverbs 13:24, "He who spareth the rod hateth his son: but he that loveth him correcteth him betimes" (Proverbs 13:24) and "Withhold not correction from a child: for if thou strike him with the rod, he shall not die. Thou shalt beat him with the rod, and deliver his soul from hell" (Proverbs 23:13-14). This text suggests that when a child does not feel the consequence of his/her sin, he/she will not understand that sin requires punishment. In the context of verse 1314, "die" means spiritual death. Children who respect authority and feel sorrowful or remorseful for their sins are pretty much likely to ask Jesus to forgive them and in return receive absolution. Discipline is critical for wisdom (Proverbs 29:15), and a child who obeys his parents will be wise (Proverbs 13:1). Even adults who do not heed correction will feel the consequences of their foolishness (Proverbs 10:13). In the same line of thought, Du Preez and Roux (2010:14) note that the notion of discipline has evolved from a focus on what children should not do, in which case corporal punishment will be used to correct unwanted behaviour, to an emphasis on what the child ought to do in order to promote selfdisciplined dispositions. 
In order to take the reader through the history of traditional school discipline practice in South Africa we want to highlight the fact the common means for maintaining discipline was corporal punishment, which was often by caning. This traditional school discipline practice draws from Victorian and Calvinist world views. These views start with the notion of loco parentis, which permits school authorities to assume full responsibility for children's upbringing, which includes the right of discipline and control. Notwithstanding the ratification on human rights and children's rights by international protocols, the literature shows that caning remains a common practice in schools in some Asian, African and Caribbean countries. While acknowledging that the administration of punishment is legalised in other countries, Nakpodia (2010:147) laments the fact that the administration of punishment cannot be ruled out in the control and discipline of students. Although it has been emphasised that school authorities have the right to punish students for breach of school regulations, the administration of punishment that entails physical chastisement needs to be done with caution (Nakpodia, 2010:147). Thus corporal punishment ought not to be inflicted in the manner or with such force as may be considered cruel or excessive. We should hasten to mention that in South Africa corporal punishment has been abolished through a legislated process by parliament. We will come back to this point in more detail below.

Discipline is often associated with authoritarianism and repression. As Foucault (1995:138) points out, it is "a policy of coercions that acts upon the body, a calculated manipulation of its elements, its gestures, its behaviour. Hence discipline produces subjected and practiced bodies, 'docile' bodies'. We should hasten to mention that school discipline entails more than punishment. Rather it is complex and includes developing students' self-discipline. As Duckworth (2009:536) points out, "self-discipline is the ability to marshal will power to accomplish goals and uphold standards that one personally regards as desirable. That is, self-discipline isn't the capacity to do what other people order you to do; rather, it is the capacity to do what you want to do. It's knowing how to manage our emotions and thoughts and knowing how to plan your behaviour so you can reach your goals". It is Osher, Bear, Sprague \& Doyle's (2010:48) contention that "the interactions that produce disciplined behaviour (or indiscipline) are mediated and/or moderated by the developmental needs of students; teacher, student, and school culture; student socio-economic status; school and classroom composition and structure; pedagogical demands; student and teacher role expectations and capacity to meet the institutionally established expectations for their roles; and school climate".

Given available literature (Osher et al., 2010; Smith et al., 2010; Daniel \& Poole, 2009; Waters, 2009; Cameron \& Sheppard, 2006; Sallis et al., 2006; Nigg et al., 2005; Arum, 2000) which recommends the adoption of an ecological approach to classroom management in improving discipline in schools, it is not unusual that in the latter half of the twentieth century, corporal punishment became a highly questionable practice, especially in democratically governed countries. The reason for this was the perceived negative effects it could have on students' behaviour as well as their emotional wellness. With the abolishing of corporal in most countries (the USA, Australia, New South Wales, and most recently, South Africa), due mainly to the advent of liberal democracy with its emphasis on individual liberties and fundamental human rights; the ratification of human and children's rights by the United Nation's international protocols, school discipline and student misbehaviour have become major bones of contention in most nation states. Most of these nation states have initiated 'zero tolerance' policies that aim to curb escalating incidents of ill-discipline in schools. Thus the resonance between school discipline and criminal justice has become evident, to the extent that schools worldwide have adopted a significant number of punitive practices and policies that enable them to optimally respond to student misbehaviour. These include surveillance cameras, metal detectors, drug-sniffing dogs, and sometimes the full-time presence of law enforcement officers - police, on school grounds.

Another possible philosophical account of discipline is social reproduction theory. School discipline, as a social construct, is synonymous with power. There is a strong connection between power and social reproduction. Power as a tool of social reproduction shapes individuals (students) to be able to play a part in power's operations. Schools are institutions for social reproduction and the schools are key sites for the reproduction of social identities and unequal of power. On the one hand, schools serve the purpose of social phenomena of reproduction and transformation. On the other hand, schools become sites for students' struggles and oppositional practices that however, often lead students to participate in their own domination. This article assumes that the theoretical notions of cultural capital, symbolic violence, and social capital articulated by Bourdieu $(1973,1977,1991)$, and Bourdieu and Passeron (1977) can serve as analytical tools for achieving a greater understanding of social phenomena of reproduction and transformation.

The concept of cultural capital (Bourdieu, 1973, 1977, 1991; Bourdieu \& Passeron, 1977) refers to language use, skills, and orientations, dispositions, attitudes, and schemes of perception (also collectively called habitus) into which children are initiated through socialization in their families and communities. French sociologist, anthropologist and philosopher Pierre Bourdieu defines 'habitus' as a system of lasting, transposable dispositions which, integrating past experiences, functions at every moment as a matrix of perceptions, appreciations, and actions and makes possible the achievement of infinitely diversified tasks, thanks to analogical transfers of schemes permitting the solution of similarly 
shaped problems.

To close off this section, we want to argue that teachers might be regarded as agents of bureaucratic hegemony, for good or for ill, in any society. Bourdieu's theory about the role of schools and teachers in the transmission of intergenerational inequalities rests on a number of assumptions about the teacher population and the school context. As Tzanakis (2011:81) notes, first there is a need to verify empirically the role of the school in promoting arbitrary cultural values via teachers. We need to establish that teachers' cultural values, net of all other demographics, are qualitatively and quantitatively significantly different from those of the average public. Second, we need to examine the effect of school context, on the grades teachers give in assessing student progress net of teachers" cultural capital and demographics. The role of the school is to promote arbitrary cultural values (school discipline, classroom order) via teachers; and on the grades teachers give in assessing student progress net of teachers' cultural capital and demographics. Teachers' assessment of students, however, reflects not only students' aptitude and performance, but also their work habits, basic communicative and other non-cognitive skills. There is a fundamental relationship between notions of cultural capital, symbolic violence, social capital and the state. The nature of this relationship demonstrates the role of power, politics, and ideology in accounting for historical trends in social capital formation and deterioration.

\section{Rethinking School Disciplne within Restorative Justice Framework}

To this day, the continued administration of corporal punishment in schools is evident despite Section 12 of the South African Constitution Act (108 of 1996) which states that "everyone has the right not to be treated or punished in a cruel, inhuman or degrading way". Nevertheless, it is appealing to start this section by asking (1) what good comes of corporal punishment?; and (2) how does corporal punishment help to make the teaching and learning environment a better place? In keeping with these questions we hold that following the flawed cultural practices, Victorian, behaviourist, positivist and Calvinist world views, much more Restorative Justice Principles and guide lines are needed for guiding and informing the current school discipline theory and practice. The need is especially apparent in schools that still rely on traditional school discipline practice and "one-size-fits-all" approaches of managing student behaviour. It is worth emphasizing that a great deal of research conducted in the area of school discipline practices identifies not only strategies and models but also characteristics of effective school discipline practice. What is also interesting about school discipline practices is that as a social construct, it has grown out of a combination of history, politics, culture, class, values and ethics. Most importantly, school discipline practices, as social construction of reality, address the cultural factors and social dynamics that generate and maintain values and beliefs. Arguably therefore, education is never value-free. Given that school discipline is not possible without avoiding teaching values, effective school discipline approaches need to be compatible with Restorative Justice Values.

While Restorative Justice is an old concept that also has a rich history, it is receiving increased greater attention among contemporary researchers and practitioners. As is so aptly put by Zernova (2007:38), a key feature of the restorative way of thinking about crime and justice is its rejection of the response to crime which considers imposition of pain on offenders normative and balances harm which an offender has caused by harm done to him or her. Restorative justice is deeply embedded in the assumption that the punitive response is 'unacceptable and ineffective. However, the concept of 'restorative justice' has appeared in written sources since the first half of the nineteenth century. In its loosest sense, restorative justice seeks a holistic, integrated sense of justice and healing for victims, as well as personal accountability from offenders. Restorative justice is a theory of justice that relies on reconciliation rather than punishment. Morrison \& Vaandering (2012:139) observe that it (1) is grounded on relational pedagogy, praxis, and discipline, and employs a responsive regulatory approach that identifies social engagement as the key element for creating rich motivational ecologies that nurture bonds of belonging; and (2) it employs a responsive regulatory approach that identifies social engagement as the key element for creating rich motivational ecologies that nurture bonds of belonging. School discipline, based on the principles of 'restorative justice' is best understood as a distinct praxis for sustaining safe and just school communities, grounded on the premise that human beings are relational and thrive in contexts of social engagement over control (Morrison \& Vaandering, 2012:139).

While we recognise the critics of restorative justice, increasingly, the use of its principles in education has been successfully implemented in schools since the early 1990s in Australia, Brazil, Canada, Indonesia, Japan, New Zealand, the United Kingdom, and the United States (Ashley \& Burke, 2010; Zernova, 2007). Restorative justice actively involves the victim of the infraction in addressing the offender directly to hold them accountable and give them a chance to explain their actions. The table below captures a comparison of punitive and restorative justice. 
Table 1: A Comparison between Punitive and Restorative Justice

\begin{tabular}{|l|l|}
\hline Punitive & \multicolumn{1}{|c|}{ Restorative } \\
\hline $\begin{array}{l}\text { Misbehaviour defined as breaking school rules or letting the } \\
\text { school down. }\end{array}$ & $\begin{array}{l}\text { Misbehaviour defined as harm (emotional/mental/physical) done } \\
\text { to one person/group by another. }\end{array}$ \\
\hline Focus is on what happened and establishing blame or guilt. & $\begin{array}{l}\text { Focus on problem-solving by expressing feelings and needs and } \\
\text { exploring how to address problems in the future. }\end{array}$ \\
\hline $\begin{array}{l}\text { Adversarial relationship and process. Includes an authority figure } \\
\text { with the power to decide on penalty, in conflict with wrongdoer. }\end{array}$ & $\begin{array}{l}\text { Dialogue and negotiation, with everyone involved in the } \\
\text { communication and cooperation with each other. }\end{array}$ \\
\hline $\begin{array}{l}\text { Imposition of pain or unpleasantness to punish and } \\
\text { deter/prevent. }\end{array}$ & $\begin{array}{l}\text { Restitution as a means of restoring both parties, the goal being } \\
\text { reconciliation and acknowledging responsibility for choices. }\end{array}$ \\
\hline Attention to rules and adherence to due process. & $\begin{array}{l}\text { Attention to relationships and achievement of a mutually desired } \\
\text { outcome. }\end{array}$ \\
\hline $\begin{array}{l}\text { Conflict/wrongdoing represented as impersonal and abstract: } \\
\text { individual versus school. }\end{array}$ & $\begin{array}{l}\text { Conflict/wrongdoing recognised as interpersonal conflicts with } \\
\text { opportunity for learning. }\end{array}$ \\
\hline One social injury compounded by another. & Focus on repair of social injury/damage. \\
\hline $\begin{array}{l}\text { School community as spectators, represented by member of } \\
\text { staff dealing with the situation; those directly affected uninvolved } \\
\text { and powerless. }\end{array}$ & $\begin{array}{l}\text { School community involved in facilitating restoration; those } \\
\text { affected taken into consideration; empowerment. }\end{array}$ \\
\hline Accountability defined in terms of receiving punishment. & $\begin{array}{l}\text { Accountability defined as understanding impact of actions, taking } \\
\text { responsibility for choices, and suggesting ways to repair harm. }\end{array}$ \\
\hline
\end{tabular}

Adapted from Ashley and Burke (2010) Implementing Restorative Justice: A Guide for Schools.

Drawing on Table 1, and given a growing dissatisfaction with traditional approaches to school-based discipline and the flawed world views indicated above, in this article we propose that current school discipline practice should move from a one-size-fits-all regulatory framework to one that recognises and embraces the principles of restorative justice. Most significantly restorative philosophy demands a major shift in thinking and the realignment (even replacement) of beliefs about discipline, its purpose and practice. There is therefore a great need to move from a punitive rule based discipline system to a system underpinned by relational values that require a change in the hearts and minds of teachers, students, their parents and the wider community. Among others, restorative justice emphasises values of empathy, respect, honesty, acceptance, responsibility, and accountability. Four points can be noted regarding the advantages of restorative justice. As Ashley and Burke (2010:7) write, restorative justice:

- Provides ways to effectively address behaviour and other complex school issues;

- Offers a supportive environment that can improve learning;

- Improves safety by preventing future harm, and

- Offers alternatives to suspension and expulsion.

To end this section, we conceive of restorative justice as a potent antidote to the contemporary school discipline problems. This is because restorative justice has the theoretical innovation to deconstruct current school discipline practice. For us, it is a most promising alternative given that it goes against the grain of the above mentioned flawed world views on discipline. Current school discipline policies of corporal punishment, suspension and expulsion only serve to maintain status quo of an authoritarian order, and reduce the democratic tendencies of collaboration, community, and resolution. In addition, these school discipline policies clearly work to marginalise learners in an increasingly diverse, ever-changing democracy. It is our contention that by tapping into the theory and practice of restorative justice, the South African education system can move towards quality education rather than punitive discipline in schools. It can, moreover, begin to develop new educational practices and protocols that can lead to creation of a more democratic citizenry.

\section{Conclusion}

Managing discipline in schools is a complex issue that ought to involve all members of the school and the wider educational community. Schools as social institutions and state apparatuses can play a critical role in effecting the ideal of democracy in South Africa. And if teachers are to effectively manage school discipline they need to grasp the nuances of restorative justice. This is necessary because failure to transcend the underlying assumptions of restorative justice can potentially perpetuate domination, social inequalities and reproduction, and result in the creation of 'docile bodies', or passive communities. For this reason, we made a case that there is need to re-imagine school discipline policies (as living documents) and approaches within the framework of restorative justice. Finally, we are acutely aware that 
restorative justice is neither panacea nor an uncontested route to take. However, it is our view that it has the potential for dialogue and negotiation, restitution and accountability, all of which are essential for fashioning a democratic citizenry.

\section{References}

Arum, R. (2000) "Schools and Communities: Ecological and Institutional Dimensions Author(s)", .Annual Review of Sociology, 26: 395418.

Ashley, J., \& Burke, K. (2010) Implementing Restorative Justice: A Guide for Schools. The Illinois Criminal Justice Information Authority: Illinois.

Bourdieu, P., \& Passeron, J.C. (2000) Reproduction in Education, Society and Culture, Sage Publications: London.

Cameron, M. \& Sheppard, S. M. (2006) "School Discipline and Social Work Practice: Application of Research and Theory", Children \& Schools, 28 (1), 15-22.

Christie, P. (1998) "Schools as (Dis) Organizations: the 'breakdown of the culture of learning and teaching' in South African schools", Cambridge Journal of Education, 28(3), 283-300.

Daniel, D. B., \& Poole, D. A. (2009) "Learning for Life: An Ecological Approach to Pedagogical Research", Perspectives on Psychological Science, 4(1), 91-96.

Dartnell, M. (2008) "Disciplining Perceptions, Punishing Violations: Captivity in Televisual Narratives of the Iraq Conflict", in Leatherman, J. (ed.) Discipline and Punishment in Global Politics: Illusions of Control, Palgrave Macmillan: New York, pp.139-164.

Deacon, R. (1996) "Discourses of Discipline in South Africa: rethinking critical pedagogies in postmodernity, Discourse", Studies in the Cultural Politics of Education, 17 (2), 227-242.

Duckworth (2009) "Backtalk: Self-Discipline Is Empowering", Phi Delta Kappan, 90 (7), 536.

Du Preez, P., \& Roux, C. (2010) "Human rights values or cultural values? Pursuing values to maintain positive discipline in multicultural schools", South African Journal of Education, 30:13-26.

Dwyer, P. J. (1995)"Foucault, Docile Bodies and Post-Compulsory Education in Australia", British Journal of Sociology of Education, 16(4), 467-477.

Foucault, M. (1995) Discipline and Punish: The Birth of Prison, Vintage Books: New York.

Freire, P. (1998). Pedagogy of Freedom: Ethics, Democracy, and Civic Courage, Rowman \& Littlefield Publishers: New York.

Leatherman, J. (2008) "Challenges to Authority in Global Politics", in Leatherman, J. (ed.) Discipline and Punishment in Global Politics: Illusions of Control, Palgrave Macmillan: New York, pp. 1-25.

Mertus, J. \& Rawls, K. (2008) "Crossing the Line: Insights from Foucault on the United States and Torture", in Janie Leatherman (ed.) Discipline and Punishment in Global Politics: Illusions of Control, Palgrave Macmillan: New York, pp. 27-40.

Mokhele, P. R. (2006) "The teacher-learner relationship in the management of discipline in public high schools", Africa Education Review, 3(1\&2), 148-159.

Morrison B. E., \& Vaandering, D. (2012) "Restorative Justice: Pedagogy, Praxis, and Discipline", Journal of School Violence, 11 (2), 138155.

Nakpodia, E. D. (2010) “Teachers' disciplinary approaches to students' discipline problems in Nigerian secondary schools", International NGO Journal, 5(6), 144-151.

Ndofirepi, A., Makaye, J., \& Ndofirepi E. E. S. (2012) "To discipline or to punish? A critical discourse on schooling in South Africa", Greener Journal of Educational Research, 2 (4), 83 - 90.

Nigg, C., Maddock, J., Yamauchi, J., Pressler, V., Wood, B., \& Jackson, S. (2005) "The Healthy Hawaii Initiative: A Social Ecological Approach Promoting Healthy Communities", American Journal of Health Promotion, 19(4), 310-313.

Onderi, H. L. N., \& Odera, F. Y. (2012) "Discipline as a tool for effective school management", Educational Research, 3(9), 710-716.

Osher, D., Bear, G.G., Sprague, J.R., \& Doyle, W. (2010) How Can We Improve School Discipline? Educational Researcher, 39(1), pp.48-58.

Sallis, J. F., Cervero, R. B., \& Ascher, W. (2006) "An ecological approach to creating active living communities", Annual Review of Public Health, 27: 297-322.

Skiba, R.J., Eckes, S. E., \& Brown, K. (2009/10) "African American Disproportionality in School Discipline: The Divide Between Best Evidence and Legal Remedy", New York Law School Law Review, 54:1071-1112.

Smith, E.P., Connell, C. M., Wright, G., Sizer, M., Norman, J. M., Hurley, A., \& Walker, S. N. (1997) "An Ecological Model of Home, School, and Community Partnerships: Implications for Research and Practice", Journal of Educational and Psychological Consultation, 8(4): 339-360.

Tzanakis, M. (2011) "Bourdieu's Social Reproduction Thesis and the Role of Cultural Capital in Educational Attainment: A Critical Review of Key Empirical Studies", Educate, 11 (1), 76-90.

Waters S. K., Cross, D. S., \& Runions, K. (2009) "Social and ecological structures supporting adolescent connectedness to school: a theoretical model", Journal School Health, 79: 516-524.

Wayson, W. W., \& Lasley, T. J (1984) "Climates for Excellence: Schools that Foster Self-discipline", Phi Delta Kappan, 65 (6), 419-421.

Yang, K.W. (2009) "Discipline or Punish? Some Suggestions for School Policy and Teacher Practice", Language Arts, 87(1), 49-61.

Zernova, M. (2007) Restorative justice: Ideals and Realities. Ashgate Publishing Limited: Hampshire. 